\title{
Information Science in Dialogue with Archival Science, Library Science and Museum Studies: The Recent Brazilian Experience
}

\author{
Carlos Alberto Ávila Araújo \\ ORCID: 0000-0003-0993-1912 \\ School of Information Science, \\ Federal University of Minas Gerais, Brazil
}

\begin{abstract}
Purpose/Thesis: In this article we discuss the theoretical common ground of archival science, library science and museum studies share with one another and with information science.

Approach/Method: The article offers a systematic review of scholarship in each of the disciplines discussed, starting with foundational texts and progressing through different periods, geographical areas, and traditions of thought.

Results and conclusions: We present the historical context in which the three disciplines were established and identify the twentieth-century theoretical developments that resulting rejection of the previously dominant paradigm. We conclude that the concept of information as studied recently may favor the advancement of theoretical perspectives in the three areas and points to the possibility of its epistemological dialogue.

Research limitations: The literature review focused on the studies that had the most significant impact on Brazilian scholarship. It could be extended to other countries, and other theories.

Practical implications: The results of the presented research may provide a conceptual basis for university courses in archival science, library science and museum studies, as they already do in Brazil. They may also inspire a comparison with other countries.

Originality/Value: There are only few studies which combine the analysis of archival science, library science and museum studies; even less relate these disciplines to information science. We believe that considering the theoretical frameworks of all these disciplines together will be beneficial for all.
\end{abstract}

\section{Keywords}

Archival science. Information science. Library science. Museum studies.

Received: 22 May 2020. Reviewed: 22 August 2020. Revised: 21 September 2020.

Accepted: 16 October 2020.

\section{Introduction}

Several undergraduate programs in archival science and museum studies were recently created in Brazil, many of them in colleges, schools or departments of information science, which, in almost all cases, already offered undergraduate programs in library science. Once the introduction of these courses was possible on the institutional level, there still remained a need to establish a theoretical common ground between these theories - indeed, it is a permanent process of scientific construction, a task to be carried out in everyday teaching 
and research. This text argues that it is possible and desirable to promote the dialogue epistemological integration between the disciplines of archival science, library science and museum studies in information science, which should occur in specific theoretical conditions we will analyze below. We will demonstrate that throughout the twentieth century the theoretical evolution of the three disciplines (as well as certain practical developments) often blurred the boundaries between them - and therefore, furthered their integration. Accordingly, information science and the concept of information itself will be central to the future developments of these three disciplines.

To support our argument we discuss the development of these disciplines, without the pretension of providing an exhaustive history. Our interest is in the epistemological aspect, in the production of knowledge about the meaning of each of these disciplines, and in the attempts to conceptualize each discipline from a specific theoretical perspective. Accordingly, the analysis focuses on these disciplines' theoretical frameworks. After a brief discussion of the information science, we discuss the two frameworks together to support our argument in favor of epistemological integration.

Different authors studied the dialogue between these disciplines. Otlet (1934) and Briet (1951) suggested it; the "merger" of the three disciplines we will be discussing below is also encouraged by authors such as Buckland (1997), Bates (2007), and Given \& McTavish (2010). Several other authors propose joint professional or institutional action and services, e.g. Usherwood, Wilson \& Bryson (2005), Wythe (2007), Yarrow, Clubb \& Draper (2008), Trant (2009), Maron, Yun \& Pickle (2013) and Accart (2014). Scholars of digital humanities and common services known as GLAM (galleries, libraries, archives, and museums), such as Zorich, Waibel \& Erway (2008), Zorich (2010), and Marcum (2014), should be mentioned as well.

Our approach is based on a specific systematic literature review of each of these disciplines, with foundational texts as a starting point, progressing through different periods, geographical areas, and traditions of thought. The texts were selected from the reading lists of courses such as "introduction to", or "fundamentals of", present in undergraduate programs in archival science (15 programs), library science (37 programs) and museum studies (14 programs), and postgraduate programs (15 programs) in Brazil.

\section{From origins to a disciplinary and paradigmatic consolidation}

Reflecting on the disciplines of archival science, library science and museum studies begins with attending to the first human cultural activities - understood here as symbolic actions of interpreting the world and producing material records of these interpretations as a physical support of any type. But it is with the invention of writing and the finding of the first cities, at the beginning of the processes of urbanization, more than five thousand years ago, that we find the earliest records of specific spaces dedicated to the preservation of documentary collections. Authors studying the history of archives, libraries and museums often list specific institutions which have been accepted as models, although very rigid distinctions of what would be an archive, library or museum do not adequately describe reality (Silva, 2006). Numerous archives, libraries and museums were established and functioned in Ancient Egypt, Greece and Rome, in the Arab and Chinese worlds and, in the medieval period, in Europe. 
However, we find the first traces of theoretical reflection on these disciplines only in the early modern period, when the first most significative treatises on these institutions were published. It was at this time that the interest in human production, as represented by artistic, philosophical and scientific works - both classical and contemporary is reborn.

Between the fifteenth and seventeenth centuries, text we recognize today as theoretical studies of archival or library sciences focused on regulating of the functioning of the institutions responsible for storage, conservation and description (accounting for legitimacy, provenance, and other characteristics) of their collections. The concept of "treasure", an object that would need to be preserved in a specific manner, emerges with the development of archival and library practices, and becomes the core of the idea of a "heritage" (a selection of intellectual and aesthetic works to be preserved and passed on to future generations).

Human symbolic production understood as a "treasure" that would need to be properly preserved, becomes the subject matter of a patrimonialist vision (the set of intellectual and aesthetic human production, to be preserved and passed on to future generations). However, the focus there was on the content of the collections, with no archives, libraries and museums functioning outside institutions dedicated to the study of literature, arts, history and sciences. At that time, there was no consistent archival, library or museological knowledge (to complement operational rules following from the common sense), but only artistic, literary, philosophical or historical knowledge of the contents stored in these institutions.

The norms of articulating knowledge regarding the functioning of libraries, archives and museums changed in the period following the French Revolution and other bourgeois revolutions in Europe, now regarded as the beginning of the modern period. Nineteenth century witnessed a profound transformation in all dimensions of human life (in politics, in economics, in law), and accordingly archives, libraries and museums transformed as well. It was then that the modern concepts of "National Archives", "National Library", "National Museum", which have a distinctly public character (as "National" invokes the collective of the nascent modern states) were used for the first time. These national institutions acquired large collections, which reinforced their custodial role. Their need for qualified personnel resulted in the establishment of the first vocational courses, focused on these institutions' functioning and supplemented by general humanistic knowledge (the subjects of the collections preserved).

Finally, with the consolidation of modern science as a legitimate form of knowledge production and intervention in nature and society, humanities became subject to the standards of a scientific discipline. Throughout the nineteenth century, various manuals seeking to establish the project of a scientific constitution of archival science, library science and museum studies were published. The nineteenth-century model of science based on natural sciences, focusing on regularities and laws with an aim of intervening in nature through technical and technological processes, was expanded to the social and human sciences as a part of the turn towards Positivism. This model inspired scientific development in the archival science, library science, and museum studies, privileging technical procedures: inventorying, cataloging, describing, classifying and ordering the documentary collections. It had a real "metonymic effect": what had once been a part of the process (technical operations to facilitate the use of collections) became the core, and in some cases, exclusive, content of the nascent disciplines. Archival science, library science and museum studies became the (positive) sciences aiming to develop the techniques of treatment of the collections at 
the related institutions. At the same time, the positivist consolidation of these disciplines promoted their "liberation" from other disciplines of which they had been only auxiliary fields (such as arts, history, literature) and their scientific autonomization, through which it enacted an effective separation between these disciplines.

There are more similarities than differences between the three disciplines. They all prioritize the "treasures" which must be guarded, assuming the importance of human symbolic production. Although syncretism of the previous centuries did not disappear altogether, there was a distinction between archives, libraries and museums. Nineteenth century witnessed specialization of institutions, archives, libraries and museums, which organized structures and routines for the exercise of custody. The positivist foundation furthered the particularity of the techniques each institution used to treat its collections. Thus, we can observe in the late nineteenth and early twentieth century the consolidation of a custodial and technical paradigm for these three disciplines (Silva, 2006). It framed these institutions' collections as heritage, focusing on their value for the future generations. It is custodial in its privileging of custody and preservation of the collections. And it is technical by centering the procedures for the identification, description and representation of documents.

One of the most visible effects of this model was that, by privileging the physical dimension of the collections, the institutions that keep them and the techniques these institutions employ to treat them, it promoted the separation of the three disciplines and their constitution as autonomous sciences. This was followed in the first decades of the twentieth century by the decisions of the professional associations to distinguish between archival, library and museum professionals. Different professionals in different institutions, employed different techniques for the treatment of specific collections - such was the result of the theoretical transformation, i.e., the custodial paradigm, and the practical developments that followed: the strengthening of institutions, professional and associative movements, and the beginning of the first university courses (Bolaños, 2002; Delsalle, 1998; López Cózar, 2002; Silva, 2006).

However, throughout the twentieth century, the theoretical development in the three disciplines did not strengthen the dominant paradigm. On the contrary, later scholarship very often commented on the various limits of this model, emphasizing those aspects that eventually made evident the need to overcome it. Furthermore, larger changes in Brazil (such as the increasing importance of information and knowledge in agricultural primary production, the development of digital technologies, the increasing interdisciplinarity of practice in the scientific community and the increasing specialization of social sciences) contributed to the transformation of archives, libraries and museums, inspiring practical initiatives that revealed the limits of the dominant paradigm. In the midst of these changes, information science emerged as an independent discipline, sharing research objects with archival science, library science, and museum studies - which we will discuss in more detail below.

\section{Theoretical developments in the twentieth century}

The diversity of scientific and theoretical knowledge produced in archives, libraries and museums, both in natural sciences and in other disciplines (such as history, pedagogy, literature) makes a comprehensive summary extremely difficult. For the purposes of this 
article, we opted to organize the varied contributions according to their engagements with the custodial and technicist paradigm.

\subsection{The functionalist studies}

By the end of the nineteenth century, essays, manifestos and initiatives called for changes in archives, libraries and museums, by means of expressions such as "effective archive", "living library", "dynamic museum", among others. They criticized these institutions' exclusive focus on their collections and their techniques, suggesting that they "move", seeking to actively engage with the social contexts in which they function. Moreover, they also introduced considerable changes to theoretical formulations.

All these texts based on functionalism, a vision of human reality inspired by a biological understanding of a living organism. Human society is understood as an organic whole, composed of parts that perform specific functions necessary for the maintenance of the balance of the whole set. Functionalist studies are therefore concerned with determining the functions (in this case, of archives, libraries and museums), to verify whether the functions are being fulfilled or not (and to identify and eliminate the obstacles to their fulfillment), and to identify the dysfunctions that may be occurring and formulate of strategies to overcome them. This vision prioritizes effectiveness: it construes scientific research as a means to boost the proper functioning of institutions and, consequently, further the development and progress of societies.

The first manifestations of this thought in the discipline of archival science are found in Jenkinson's and Casanova's pioneering manuals (published in 1922 and 1928, respectively) which argued that archives should be effectively organized to support general organizational efficiency. But it was with the development of records management, tasked specifically with the elimination of documents, that a more effective pragmatist thought was formulated in the works by Warren, Brooks, and especially Schellenberg, who discussed primary and secondary value of archival documents (Delsalle, 2000). Together, their proposals aimed at preserving a maximum information and a minimum of documents - prioritizing the function of the documents as opposed to their historical value. Another aspect of the functionalist attitude to the archives was prioritizing their cultural and pedagogical functions. This inspired interest in a greater "dynamization" of these institutions (Alberch i Fugueras et al., 2001).

To find the first effectively public libraries, it is necessary to return to the mid-eighteenth century. They were first established in England and later in the USA (Murison, 1988). We use the term "effectively" to emphasize that the first modern libraries, while "public" in the name, were not established with the general public in mind. Acts, manifestoes and practical initiatives concerned with public libraries (public library movements), led by librarians such as Mann and Barnard, sought to break their isolation and attract more people into their space. As early as 1876, Green, as a forerunner of the so-called reference services, advocated practical innovations in libraries to increase physical and intellectual accessibility (Fonseca, 1992). Library science was formally established as a discipline at the University of Chicago, where the first program for graduate study was established in 1928. Authors such as Butler, Shera, Danton, and Williamson advocated a scientific approach to library science, not to study its technical processes but to analyze the fulfillment of their social functions. Thus, the library was understood primarily in relation to the social needs 
it met (Norman, 1988; Shera, 1972). Shera proposed a new field for the study of the role of knowledge in society, social epistemology (Martínez-Ávila \& Zandonade, 2020; Zandonade, 2004). Theorists from different countries, such as Lasso de la Vega, Litton, Buonocore, Mukherjee and Usherwood, followed the argument that a library was a democratic, active institution, rather than a depository of books (López Cózar, 2002). In India, Ranganathan, developed the five "laws" of library science, advocating for the effective use of the library and its resources while library continued to meet the needs of society, accounting for all its parts. Later developments in the laws of library science, such as those introduced by Thompson (1974) and Urquhart (1981) also prioritized social functions and the need for libraries to be dynamic and active.

The main development in the discipline of museum studies occurred in the area of museum education, primarily in the Anglophone scholarly community. According to Gómez Martínez (2006), it is a "verbal" museology, oriented towards action, established in opposition to the tradition whose major symbol would be the Louvre - the so-called "nominalist" tradition, aimed at the possession and description of objects. Zeller (1989) points out that museum studies focused on the efficiency of museums, effective propagation of certain values to the population, and the "return" on the investments it made. Authors such as Flower, Goode, Dana, Rea, and Coleman remarked on the specificity of the new museums as institutions that would have value not in the opportunity for contemplation they may present, but in use; which would not wait for the visitors, but reach out to them, drawing them by eliminating barriers and increasing accessibility (Carbonell, 2012; Zeller, 1989). Several museums entered into partnerships with the private sector to increase industrial and commercial activities, resulting in museographic innovations (Bolaños, 2002). This trend is apparent outside Brazil as well. The imaginary museum of Malraux and the Pompidou Center in Beaubourg in France stand out as examples of, respectively, great theoretical and practical innovation (Rivière, 1993). Canadian museums approached the concept of "communication" present in the works of Cameron (1968), emphasizing communication between museums and their public.

Since the 1980s and the advent of digital technology, with its possibilities of remote access and interactive exhibitions, the functionalist current has been revitalized which might be observed, for example, in the work by the group of researchers affiliated with the University of Leicester (Merriman, Pearce, Arnold, Hooper-Greenhill, and others) and, Vergo's concept of "new museum studies" (1991).

\subsection{The Critical Perspective}

Critical approaches to social phenomena have been developing intensely since the nineteenth century in response to Positivism. While recent social sciences sought to establish patterns and regularities, critical theory denounced the historical character of reality, arguing for the study of historical contexts to understand phenomena. In opposition to functionalism, which aimed at the proper functioning of the society's parts, critical theory argued that social reality became intelligible in conflict, rather than integration. Critical approaches, characteristically premised on suspicion, have developed in practically all social and human sciences, including the disciplines of archival science, library science and museum studies. Scholars studied archives, libraries and museums not in order to identify the functions they 
should perform for the improvement of the social whole; rather, they focused on their role in the dynamics of power and domination, denouncing their ideological actions.

The first traces of critical theory in archival science appear in the work of scholars such as Bautier, who studied the impact of specific ideological interests on the archives' choice of criteria in the early modern period. Other studies analyzed the power that came with the possession of documents, as in the case of the decolonization processes in Africa and Asia (Silva et al., 1998). In the 1960s and 1970s, debates of national information policies promoted by UNESCO focused on the role of archives, the issue of the right to information, and the need for the state to be transparent (Jardim, 1995). Presenting a radically different argument, authors such as Colombo (1992) warned against the obsession of contemporary societies with archiving and recording of human activities. The critical perspectives most important to contemporary archival science were developed in Canada. Following Terry Cook's work (2013), scholars sought to overcome the assumption of the neutrality and passivity of archival practices, analyzing archives as spaces in which power relations are negotiated, contested, and confirmed, shifting emphasis from collections to contexts. Authors such as Caswell (2010), Harris (2007) and Montgomery (1995) studied specific archival realities, for example in totalitarian regimes, developing Cork's work with a reference to theoretical frameworks developed by Hannah Arendt and Jacques Derrida.

Critical theory first manifested in library science in developing countries in relation to the processes of redemocratization following the fall of military dictatorships. At first, such manifestations mostly practical (e.g., creation of new library services, such as the library-car), and aimed to increase socially excluded populations' access to knowledge. Years later, these practices were theorized as a part of more general reflections on cultural action and cultural animation, in which different types of cultural ideologies were distinguished, with the expectation that the librarian would identify them and act before them, the librarian would identify them and act before them with "emancipation", rather than "domestication" as their goal (Flusser, 1983). The scholars postulated that libraries should be dynamic and active, and oppose the processes of alienation - a concept they used in a different sense than the functionalists (Milanesi, 2002). Critical studies have developed in France as well, where authors such as Estivals, Meyriat and Breton shared a Marxist approach to the study of different circuits of the book and the printed document (Estivals, 1981).

The first instances of critical theory in museum studies are found in the work of artists and essay writers such as Zola, Valéry and Marinetti (Bolaños, 2002), who viewed the museum as a "mausoleum", an institution that degraded art, and an instrument of power some people wielded over others. In the 1960s, a new wave of criticism provoked the emergence of "anti-museum" forms (Bolaños, 2002) and important museological innovations. However, critical theory's main contribution to the museum studies was its approach to the sociology of culture pioneered by Pierre Bourdieu (1979) and the generation of researchers he inspired. Bourdieu aligned material and symbolic dimensions, analyzing the relations of different social groups with culture (including museums). Contemporary scholars use Bourdieu's framework and his concept of cultural capital to study different museological practices (Lopes, 2007). Others study the role that museums play in the construction of the idea of a nation, following the work of Benedict Anderson. A more recent area of critical museum studies focuses on the critique of museological strategies of preserving natural and human heritage (Santacana Mestre \& Hernández Cardona, 2006). 


\subsection{User studies}

While archives, libraries and museums always had users and visitors, they were not a prominent part of the custodial paradigm. In the early twentieth century, functionalism became the attitude of the public, as various institutions sought to obtain data on satisfaction indexes for service improvement. Gradually, the interest in the users' subjective experiences grew, to the point where it became an autonomous area of study. Users and visitors were no longer only seen as the target of archival, library and museological processes, but as active agents, construing meanings and interpretations, with diverse needs and strategies. This new interest in the users changed theory and practice.

The relationship between users and archives became an object of research for archival science in the 1960s (Silva et al., 1998), as part of a wider discussion regarding the access to archives, conducted at the meetings of the International Council on Archives (ICA). However, the subject has never been widely studied. According to Jardim and Fonseca (2004), Taylor, Dowle, Dearstyne, Pugh, Cox and Wilson pioneered the study of the user in archival science, aiming to understand the information needs of different types of users. Other user studies in the field concerned with the work cultural dynamization focus on the typology of users and, more recently, on citizens and their interests in family history and in teaching (Coueré \& Duclert, 2001).

The first manifestation of the interest in users in library science were the "community studies" conducted by researchers at the University of Chicago, who focused on social groups, rather than on the individual users. They carried out various empirical studies of reading habits and sources of information, which remained an important point of reference for the next three decades. Gradually, interest shifted to the evaluation of library services, converting user studies into use studies for library diagnosis. Focusing on the evaluation of collections, these studies have promoted practical innovations, such as the selective dissemination of information. In the 1970s, researchers such as Line, Paisley, Brittain and Totterdall shifted attention to information needs, which in the next decade became the main area of user studies (Figueiredo, 1994). The 2000s brought significant studies of the school library, which employed a cognitivist perspective, identifying the use of the information in the different phases of the research process - for example, Kuhlthau's (2004) and Todd's (2003).

Users studies became a part of museum studies as a part of a wider transformation of archives from repositories of objects to places of learning. These institutions' focus moved from the collections to the public, and the visitor studies followed (Hooper-Greenhill, 1998). At the beginning of the twentieth century, first empirical studies were carried out, with Galton following the visitors through the museum corridors, and Gilman studying the fatigue and other physical problems caused by the design of exhibitions. Early rigorous investigations, sponsored by the American Museum Association, took place in the late 1920 s - the results were presented in the first visitor behavior study, published by Robinson in 1928. The 1940s witnessed a proliferation of studies on the impact on visitor exhibitions by authors such as Cummings, Derryberry and Melton. Other studies, led by authors such as Rea and Powell, traced socio-demographic profiles of visitors and mapped their cultural habits (Pérez Santos, 2000). In the 1960s, Shettel and Screven introduced a new perspective on the measures used to study visitors' learning experiences. In the following decades, 
cognitive-based approaches to the exhibitions' efficiency were developed (Eason, Friedman, Borun), together with constructivist approaches, such as Loomis's three-dimensional model, McManus's filter theory, Uzzell's sociocognitive model, Hooper-Greenhill's communicational approach and the contextual model of Falk and Dierking (Pérez Santos, 2000). All these various approaches sought to understand how users interpreted museographic exhibitions, constructing different meanings, informed by their individual experiences, background and sociocultural contexts (Davallon, 2005).

\subsection{Studies on representation}

Since their inception, archives, libraries, and museums faced the challenge of representing their collections - inventorying them for control and storage, cataloging and classifying them for retrieval purposes, describing them to facilitate access and use. Historically, such a challenge has been conceived of as a technical issue, with the objective of finding the most appropriate way to achieve the goal. In the eighteenth and nineteenth centuries, encyclopedism, historicism, positivism, and their propositions of universal schemes of representation strongly influenced the understanding of representation in these institutions. Throughout the twentieth century, however, different theories problematized this process, gradually forming a sub-field of studies strongly influenced by the language sciences.

The question of principles of organization and description of archival documents emerged and was debated throughout the period of consolidation of the custodial paradigm. Since 1898 and the publication of the Dutch manual by Muller, Feith and Fruin, it has gained a different status, opening up a space to reflect on the norms and archival techniques. Practical applications of classification tools, including bibliographic classification systems, were tested in the following years, unaccompanied by a significant theoretical reflection which followed only in later manuals, such as those of Tascón in 1960 and Tanodi in 1961, and in theoretical works of researchers such as Schellenberg. In the 1970s authors such as Laroche and Duchein problematized the principles of order by comparing the US concept of record group with the European principle of provenance. Later in that decade, authors such as Dollar and Lytle introduced the question of electronic records and information retrieval (Silva et al., 1998). Aspects of preservation and authenticity were at the center of debates on digital documents, involving researchers such as Duranti and Lodolini, who sought to confirm the value of the provenance principle and the respect for funding as a fundamental criterion of archival science. The growth of digital media also inspired research on archival standardization, based primarily on the idea of systems' interoperability and the possibility of networking, involving researchers, professional associations and governmental entities (Ribeiro, 2003).

The issues related to description and organization are the foundation of the library science as an autonomous discipline. The rules of cataloging, involving the description of the formal aspects of documents were first formulated in the nineteenth century. From the 1960s onwards, international standards of bibliographic description shared by various scholarly communities have been in operation. At the same time, first models of description accounting for reading by a computer appeared, establishing standards that, years later, would form the field known as Metadata. At the same time, classification emerged as a separate field of study with the creation of the first general and enumerative bibliographic 
classification systems, such as those created by Dewey, Otlet, Bliss, and Brown. In the first half of the twentieth century, Ranganathan's work on faceted classification revolutionized the field by proposing flexible and non-hierarchical forms of classification. His theories had a great impact on the Classification Research Group, founded in London in 1948, which brought together researchers such as Foskett, Vickery and Pendleton, engaged in the construction of faceted systems for specific domains of knowledge and problematization of classification principles (Souza, 2007). In the following years, various fields and research sectors have established a dialogue or appropriated the principles of faceted classification, among them Aitchison's faceted thesauri, Dahlberg's Concept Theory, Neelameghan's faceted database studies, Albrechtsen and Jacob's boundary objects, Kwasnik's classification structure searches, and the mapping of sentences for the facet evidence by Beghtol (1995).

The nationalist and historiographical spirit of the first modern museums informed the criteria of ordination, description, classification and exhibition of the collections (Mendes, 2009). The sub-field of museological documentation arose at the beginning of the twentieth century, inspired by the work of authors such as Wittlin, Taylor, and Schnapper (Marín Torres, 2002). These authors sought to problematize classificatory aspects of museums, such as the representation of the genres, of the different peoples of the world, of different human cultures, in line with cultural studies (Pearce, 1994). Regarding practical applications, Bolaños (2002) presented several examples of innovative methods of representation, such as Dorner's radical historicism, Prado Museum's period rooms, the multidisciplinary approach of the Museum of Modern Art in New York, the antiracist stance of the Trocadero Museum and the dynamic model of the Museum of Ethnography of Neuchâtel, and the recent development in the design of museums wherein buildings themselves become museological pieces, e.g., the Guggenheim Museum in Bilbao.

\section{Contemporary approaches flows, mediations, systems}

The most recent advances in the disciplines of archival science, library science and museum studies sought to combine the various contributions of the last decades. New types of institutions, services and actions carried out in the extra-institutional sphere have received more attention, as research has become more concerned with flows and the circulation of information. In order to revise models which focus on the action of the institutions in relation to the public, or on the public's uses and appropriations of the collections, new models emerged, prioritizing interaction and mediation, contemplating the reciprocity of the relationship between these actors. Scholars also introduced systemic models integrating actions, collections or services previously contemplated in isolation. In response to the questions about the subject matter of archival science, library science and museum studies, the very idea of a collection was problematized. Furthermore, new digital technologies transformed both the practice and theory of these disciplines.

The 1960s saw a greater theorization regarding the research object of the archive science (notably, Tanodi defined the subject matter as "archivalia" in 1961); an extension of the discipline's domains (to include administrative files, private and corporate files); and the emergence of new fields (concerned with sound files, visual files and the use of microfilm). These changes led to the creation of the Document and Archives Management Program 
(RAMP), structured by the ICA (International Council Archives) and UNESCO (United Nations Educational Scientific and Cultural Organization) and the UNESCO's General Information Program (PGI), created in 1976. The greatest theoretical innovation, the Integrated Archives, emerged in the early 1980s with the article by Ducharme and Rousseau (1980), which presented a systematic view of the documentary flow. Two years later, Couture and Rousseau (1982) formalized the quest for a synthesis of records management and the archives administration, which, according to them, should comprise an overview of the archives, accounting for the management of documents in the field of action of the archival science, i.e., encompassing the so-called three ages of the documents from an integrated perspective. This approach was later developed by authors such as Cortés Alonso and Conde Villaverde in Spain, Menne-Haritz in Germany, Cook in England and Vásquez in Argentina. Shortly thereafter, the expression "post-custodial” was coined to designate a new phase of archival science (Cook, 1997). Other recent studies focused on the relationship between archives and oral history, the field of personal and family archives (Cox, 2008), the archive mediation (Duff, 2016) and the discussion of the discipline's object as "archivalization" (Ketelaar, 2012).

Where the library science is concerned, we may distinguish two major trends in the recent scholarship. The first is known as "Mediation". The term was first used by Ortega y Gasset, in 1934, in a sense of bridge, or filter, to signify the librarian, emphasizing their role as a guide of the user's reading experience. Years later, the concept of a library underwent a structural alternation from a "collection of books and other documents, duly classified and cataloged" to "an assembly of information users" (Fonseca, 1992). Thus, the idea of mediation itself has changed, shifting the emphasis from the diffusive character (of transmission of knowledge) to the dialogical character of the library (Almeida Jr., 2009). The concept features in new librarianship (Lankes, 2011), which postulates that the function of the library is to help in the creation of knowledge in communities, and in the discussion of library as a public sphere, a space to rational argumentation regarding collective decisions on the conducting of the society (Ventura, 2002). The role of the library as a public sphere is also analyzed within the studies on mediation. It developed from the concept of information literacy, which emerged in the USA in 1974 with an intention of identifying and promoting information skills of subjects, who were no longer understood only as users with information needs (Campello, 2003; Dudziak, 2003). The third recent trend in the library studies is the study of electronic or digital libraries, and their implications for collections, services and dynamics related (Rowley, 2002).

Where museum studies are concerned, the development of the ecomuseums and the so-called New Museology deserve to be mentioned. According to Davis (1999), the concept of ecomuseum emerged at the beginning of the twentieth century, in response to environmentalism, concepts related to ecology and ecosystems: it involved creation of open-air museums, which incorporated geological or natural sites into their collection. Another meaning of the term ecomuseum features in New Museology, which rethinks of the museum as an institution (Poulot, 2002), inspired by Rivière, Hugues de Varine and Bazin. Thus understood, museums should engage local communities in the process of treating and caring for their heritage. It implies that museum studies should study the relation of people to cultural heritage and that the museum itself should be understood as an instrument and agent of social transformation - which goes beyond traditional functions of identification, 
conservation and education towards the effects of the institution's actions on its social and physical surroundings, with an aim of involving the local community. Promoting community participation over the "monologue" of an expert technician changes the traditional triad of building / collections / public of museum studies into a new network of concepts, composed of territory, heritage and community. However, New Museology must be distinguished from the recent new museum studies proposed by Vergo (1991), which revitalize functionalist thinking. Recent trends in the museum studies involve discussions of the musealization of intangible heritage (Costa, 2009). Finally, the contemporary phenomenon of virtual museums inspires various practical and theoretical developments. For Deloche (2002), the arrival of the digital technology into museums entails a reformulation of the very concept of the institution. Without a building or collections, the defining traditional institutional milestones, the museum sees itself as providing new services, through new practices and functions, to users who act in new conditions. At the same time, the adoption of technologies to treat their collections and plan exhibitions makes the museum more of an information system. These phenomena are studied in a specific field of museum informatics, which deals with sociotechnical interactions (between people, information and technology) in museum spaces (Marty \& Jones, 2008).

Contemporary developments such as the New Museology, mediation, intangible heritage, and virtual museums led to the expansion of the object of the discipline of museum studies (its organization, its techniques and its collections) into museality. As Stránský (2008) pointed out, as it is not political institutions but "the political" that is the object of study for political science, i.e., the political dimension of all human actions, so with museum studies: the object of the discipline is not the museum, the institution, but "the museum", a dimension of human action present in the most diverse contexts - including, but not limited to, actions occurring in the museum.

\section{The development of information science}

The roots of information science lie in the study of documentation, pioneered by Otlet and La Fontaine in the early twentieth century. Concerned with the availability of records on the totality of human knowledge (more than with the storage of these records), the authors developed the concept of "document", extending the scope of their research beyond books and other printed records. Although the discipline discusses archives, libraries and museums, it eventually developed as a distinct, parallel discipline, concerned mainly with scientific and technological information.

The first scholars of information science studied the registration and provision of information, as well as specific fields of science and technology (Feather \& Sturges, 2003). The attempts to institutionalize the activities of these professionals led to the establishment of information science. For Shera and Cleveland (1977), the event marking the transformation of the study of documentation into information science was the International Conference on Scientific Information, held in Washington in 1958. In the same year, the Institute of Information Scientists was founded in United Kingdom. A few years later, in 1966, the American Documentation Institute (ADI) changed its name to American Society for Information Science (ASIS), becoming the first scientific institution devoted specifically 
to information science. The theoretical foundations immediately adopted were Shannon and Weaver's Mathematical Theory of Communication, Wiener's Cybernetics, and Vannevar Bush's contributions to a systemic perspective of studies (Vickery \& Vickery, 1987). Together, they developed the scientific concept of information, the discipline's research object (the information systems) and its research agenda, expressed in an article by Borko, published in 1968, which has since then become a classic in the field (Debons et al., 1988).

Later development of information science exceeded early expectations. According to Bawden and Robinson (2012), since the 1980s information science has developed in relation to several "research programs": information organization, information technologies (creation, dissemination and retrieval), informetrics, information behavior, communicating information, information society, information management and policy, and digital literacy. The scope of the discipline's research has extended beyond physical records in information systems, to include, e.g. "invisible schools" (informal information exchange processes), "tacit knowledge", and information needs and information skills of subjects.

According to several authors (Bawden \& Robinson, 2012; Capurro, 2014; Orom, 2000; Saracevic, 1999; Salaün \& Arsenault, 2009; Vega-Almeida, Fernández Molina \& Linares, 2009), three broad models of information phenomena emerged: the physical model (which privileges the idea of information as a "thing" transferred from one point to another, or processed within a system), the cognitive model (inspired by Popper's philosophy and emphasizing information as an element altering users' mental models) and the social modal (which seeks to understand what information is to user communities, rescuing the idea of intersubjective construction). Hjørland (2018) emphasizes the importance of a culture - and social - oriented views for the study of information phenomena in recent years, while Floridi (2019) lists the qualities of contemporary societies that pose new challenges for thinking about information. Recent concepts in information science include digital curation, the open access movement, ontologies, folksonomies, domain analysis, Internet of Things, information practices, critical information literacy, information culture, information orientation, intercultural ethics of information, information regimes, altmetrics, neo-documentation and digital humanities (Araújo, 2018).

Information science has been characterized as interdisciplinary (Saracevic, 1999), post-modern (Wersig, 1993) and belonging to the field of human and social sciences (Cronin, 2009). These characteristics testify to the discipline's flexibility, its capacity for dialogue and interaction with different disciplinary fields; it is critical of the limits of positivism and sensitive to the specificities of the current "information society"; and capable of accommodating different schools and theoretical currents.

\section{Conclusion: The possibility of epistemological integration}

The developments in the theory of archival science, library science and museum studies rendered the previous custodial model obsolete. Within the custodial paradigm, these disciplines studied the stored and inherited treasures, institutional routines of the entities dedicated to their preservation and the technical procedures for the treatment of the collections. Theories developed in the twentieth century undermined the rigid boundaries between the disciplines proposing to study relations between these institutions and the 
society (both from a functionalist and a critical perspective), focusing on the subjects' experience, problematizing representations and attending to flows and mediations. Thus, the broader dynamics of processes occurring at these institutions became the object of research, which now examined the production of records (even without physical existence), the composition of the collections, the users' appropriation of the collections, and the different layers of meaning construed with professional intervention and the instruments of description and classification. In museum studies, this development is evident in the turn from "museum", "museality", or "musealization" as in the classical definition of Stránský (2008); in archival science, in the concept of "archivalization" (Ketelaar, 2012) or archival mediation (Duff, 2016); and in library science in the notion of mediation or dialogue, as in the recent discussions of information literacy, or in the new librarianship (Lankes, 2011).

These three disciplines, then, may with profit enter into dialogue with information science. An example of such dialogue appears in Bates' approach (Bates, 2015), which brings these disciplines together through the concepts of knowledge (library science), memory (archive science), and heritage (museum studies).

In addition, because information science has been from the beginning established as a scientific discipline, it may provide a space for theoretical reflection and problematization, without the pressure to establish practical, applicable rules, which dominated the early history of archival science, library science, and museum studies.

The concept of information does not have to be discussed in epistemological terms, as it was here, but also in terms of ontology: however, first it is necessary to return to very origin of the term, which, according to Capurro (2007), derives from the Greek concepts of eidos (idea) and morphé (form), meaning "to form something". Information, therefore, may be considered to be a human action on the world ("in-form"), an act apprehending it through the symbolic, naming and classifying the objects (objects of nature), creating objects to be used (instruments with the most diverse purposes), producing records that constitute new objects (printed texts, visual and sound) and creating records of these records (catalogs, indexes, inventories, etc.).

Information is, therefore, a concept central to the whole process. It originates from the production of material records and extends to human interactions (archival, library science, museological) with these records. However, its significance may be even broader: it is all that involves human action beginning with the first record, the first act of "in-forming". A part of the everyday human action of seizing the world and producing material records of this process has been institutionalized and subjected to technical procedures developed specifically to interact with these records, but information surpasses these institutions in the most diverse uses, flows, appropriations, contexts. The breadth of information science enables it to consider the various archival, library science and museum processes as more than the technical procedures defined by the custodial paradigm. Thus, it also blurs the rigid disciplinary boundaries (without negating these disciplines' identity and specifity) to the benefit of theoretical reflections and practical applications - as recently illustrated by Europeana (a comprehensive digital system which is at the same time an archive, a library and a museum of collections of European culture) or the merge of the National Archive and the National Library in Canada. Finally, information science, without imposing itself on the three disciplines, and remaining open to the specificities and contributions of each, allows a dialogue required for the development of scientific knowledge that is not reduced 
to the study and practice of the institutions that each discipline is related to. Information science makes it possible for the three disciplines to be more than "archival science", "library science", and "museum science" - and still enrich each other.

\section{References}

Accart, J.-P. (2014). Regards croisés sur les métiers des sciences de l'information: bibliothèques, archives, documentation, musées. Mont-Saint-Aignan: Éditions Klog.

Alberch i Fugueras, R. et al. (2001). Archivos y cultura: manual de dinamización. Gijón: Trea.

Almeida Jr., O. (2009). Mediação da informação e múltiplas linguagens. Tendências da Pesquisa Brasileira em Ciência da Informação, 2(1), 89-103.

Araújo, C. A. Á. (2018). O que é ciência da informação. Belo Horizonte: KMA.

Bates, M. J. (2007). Defining the Information Disciplines in Encyclopedia Development. Information Research [online], 12(4), paper colis29 [21.09.2020], http://informationr.net/ir/12-4/colis/colis29.html

Bates, M. J. (2015). The Information Professions: Knowledge, Memory, Heritage. Information Research [online], 20(1), paper 655 [21.09.2020], http://informationr.net/ir/20-1/paper655.html\#. $\mathrm{X} 4 \mathrm{mSD}-0 \mathrm{wjcs}$

Bawden, D., Robinson, L. (2012). Introduction to Information Science. London: Facet.

Beghtol, C. (1995). Mapping Sentences and Classification Schedules As Methods of Displaying Facets. Advances in Classification Research Online [online], 6, 1-12, http://doi.org/10.7152/acro.v6i1.12657

Bolaños, M. (2002). La memoria del mundo: cien años de museología: 1900-2000. Gijón: Trea.

Bourdieu, P. (1979). La distinction: critique sociale du jugement. Paris: Éditions de Minuit.

Briet, S. (1951). Qu'est-ce que la documentation? Paris: Éditions Documentaires Industrielles et Técnique.

Buckland, M. K. (1997), What is a "Document"? Journal of the American Society for Information Science, 48(9), 804-809.

Campello, B. (2003). O movimento da competência informacional: uma perspectiva para o letramento informacional. Ciência da Informação, 32(3), 28-37.

Capurro, R. (2007). Epistemología y ciencia de la información. Enl@ce: Revista Venezoelana de Información, Tecnología y Conocimiento, 4(1), 11-29.

Capurro, R. (2014). Pasado, presente y futuro de la noción de información. Logeion, 1 (1), 110-136.

Carbonell, B. M. (ed.). (2012). Museum Studies: An Antology of Contexts. West Sussex: Wiley-Blackwell.

Caswell, M. (2010). Khmer Rouge Archives: Accountability, Truth, and Memory in Cambodia. Archival Science, 10(1), 25-44.

Coeuré, S., Duclert, V. (2001). Les archives. Paris: La Découverte.

Colombo, F. (1992). Os arquivos imperfeitos: memória social e cultura eletrônica. São Paulo: Perspectiva.

Cook, T. (1997). What is Past is Prologue: A History of Archival Ideas since 1898, and the Future Paradigm Shift. Archivaria, 43(1), 17-63.

Cook, T. (2013). Evidence, Memory, Identity and Community: Four Shifting Archival Paradigms. Archival Science, 13(2), 95-120.

Costa, P. (Ed.) (2009). Museus e património imaterial: agentes, fronteiras, identidades. Lisboa: Instituto dos Museus e da Conservação; Softlimits.

Couture, C., Rousseau, J.-Y. (1982). Les archives au XXe siècle: une réponse aux besoins de l'administration et de la recherche. Montréal: Université.

Cox, R. (2008). Personal Archives and a New Archival Calling: Readings, Reflections and Ruminations. Duluth: Litwin.

Cronin, B. (2009). The Sociological Turn in Information Science. In: A. Gilchrist (ed.). Information Science in Transition (109-127). London: Facet. 
Davallon, J. (2005). Penser la muséologie. In: J. Davallon \& B. Schiele (eds.). Doctorat en Museólogie, mediation, patrimoine (69-98). Sainte-Foy: Multimondes.

Davis, P. (1999). Ecomuseums: A Sense of Place. London: Leicester University Press.

Debons, A., Horne, E., Cronenweth, S. (1988). Information Science: An Integrated View. Boston: G. K. Hall.

Deloche, B. (2002). El museo virtual. Gijón: Trea.

Delsalle, P. (2000). Une histoire de l'archivistique. Sainte-Foy: Presses de l'Université du Québec.

Ducharme, J., Rousseau, J.-Y. (1980). L'Interdépendance des archives et de la gestion des documents: une approche globale de l'archivistique. Archives, 12(1), 5-28.

Dudziak, E. (2003). Information literacy: princípios, filosofia e prática. Ciência da Informação, 32(1), 23-35.

Duff, W. (2016). Mediação arquivística. In: T. Eastwood \& H. MacNeil (eds.). Correntes atuais do pensamento arquivístico (171-202). Belo Horizonte: Ed. da UFMG.

Estivals, R. (1981). A dialética contraditória e complementar do escrito e do documento. Revista da Escola de Biblioteconomia da UFMG, 10(2), 121-152.

Feather, J., Sturges, P. (2003). International Encyclopedia of Information and Library Science. London: Routledge.

Figueiredo, N. (1994). Estudos de uso e usuários da informação. Brasília: IBICT.

Flusser, V. (1983). A biblioteca como um instrumento de ação cultural. Revista da Escola de Biblioteconomia da UFMG, 12(2), 145-169.

Fonseca, E. (1992). Introdução à biblioteconomia. São Paulo: Pioneira.

Floridi, L. (2019). The Logic of Information: A Theory of Philosophy as Conceptual Design. Oxford: Oxford University Press.

Given, L. M., McTavish, L. (2010). What's Old is New Again: The Reconvergence of Libraries, Archives and Museums in the Digital Age. Library Quarterly, 80(1), 7-32.

Gómez Martínez, J. (2006). Dos museologías: las tradiciones anglosajona y mediterránea - diferencias y contactos. Gijón: Trea.

González de Gómez, M. (2000). Metodologia de pesquisa no campo da Ciência da Informação. DataGramaZero, 1(6).

Harris, V. (2007). Archives and Justice: A South African Perspective. Chicago: Society of American Archivists.

Hjørland, B. (2018). Library and Information Science (LIS) Part 2. Knowledge Organization, 45(2), 319-338.

Hooper-Greenhill, E. (1998). Los museos y sus visitantes. Gijón: Trea.

Jardim, J. M., Fonseca, M. O. (2004). Estudos de usuários em arquivos: em busca de um estado da arte. Datagramazero, 5(5).

Jardim, J. M. (1995). Sistemas e políticas públicas de arquivos no Brasil. Niterói: EdUff.

Ketelaar, E. (2012). Cultivating Archives: Meanings and Identities. Archival Science, 12, 19-33.

Kuhlthau, C. (2004). Seeking Meaning: A Process Approach to Library and Information Services. London: Libraries Unlimited.

Lankes, D. (2011). The Atlas of New Librarianship. Cambridge: MIT Press.

Lopes, J. (2007). Da democratização à democracia cultural. Porto: Profedições.

López Cózar, E. (2002). La investigación en biblioteconomía y documentación. Gijón: Trea.

Marcum, D. (2014). Archives, Libraries, Museums: Coming Back Together? Information \& Culture: A Journal of History, 49(1), 74-89.

Marín Torres, M. T. (2002). Historia de la documentación museológica: la gestión de la memoria artística. Gijón: Trea.

Martínez-Ávila, D., Zandonade, T. (2020). Social Epistemology in Information Studies: A Consolidation. Brazilian Journal of Information Science, 14(1), 7-36. 
Maron, N., Yun, P., Pickle, S. (2013). Sustaining our Digital Future: Institutional Strategies for Digital Content. London: Strategic Content Alliance.

Marty, P., Jones, K. (eds.). (2008). Museum Informatics: People, Information and Technology in Museums. New York: Routledge.

Mendes, J. (2009). Estudos do patrimônio: museus e educação. Coimbra: Univ. Coimbra.

Milanesi, L. (2002). Biblioteca. São Paulo: Ateliê.

Montgomery, B. (1995). Archiving Human Rights: The Records of Amnesty International USA. Archivaria, 39, 108-131.

Murison, W. (1988). The Public Library: Its Origins, Purpose and Significance. London: C. Bingley.

Norman, S. (1988). The Library Quarterly in the 1930s: A Journal of Discussion's Early Years. The Library Quarterly, 58, 327-351.

Orom, A. (2000). Information Science, Historical Changes and Social Aspects: A Nordic Outlook. Journal of Documentation, 56(1), 12-26.

Otlet, P. (1934). Traité de documentation: le livre sur le livre: théorie et pratique. Bruxelles: Mundaneum.

Pearce, S. (Ed.). (1994). Museums and the Appropriation of Culture. London: Athlone.

Pérez Santos, E. (2000). Estudio de visitantes en museos: metodología y aplicaciones. Gijón: Trea.

Poulot, D. (2002). Musée et muséologie. Paris: La Découverte.

Ribeiro, F. (2003). O acesso à informação nos arquivos. Lisboa: Fundação Calouste Gulbenkian; MCT; MCEC.

Rivière, G. H. (1993). La museología: curso de museología, textos y testimonios. Madrid: Akal.

Rowley, J. (2002). A biblioteca eletrônica. Brasília: Briquet de Lemos.

Salaün, J. M., Arsenault, C. (2009). Introduction aux sciences de l'information. Montreal: Presses de l'Université de Montréal.

Santacana Mestre, J., Hernández Cardona, F. (2006). Museologia crítica. Gijón: Trea.

Saracevic, T. (1999). Information Science. Journal of the American Society for Information Science, 50(12), 1051-1063.

Shera, J. (1972). The Foundations of Education for Librarianship. New York: Becker and Hayes.

Shera, J., Cleveland, D. (1977). History and Foundations of Information Science. Journal of the American Society of information Science and Technology, 12, 249-275.

Silva, A. M. et al. (1998). Arquivística: teoria e prática de uma ciência da informação. Porto: Afrontamento.

Silva, A. M. (2006). A informação: da compreensão do fenômeno e construção do objecto científico. Porto: Afrontamento.

Souza, R. (2007). Organização do conhecimento. In: L. Toutain (Ed.). Para entender a ciência da informação. (pp. 103-123). Salvador: EdUFBA.

Stránský, Z. (2008). Sobre o tema 'Museologia - ciência ou trabalho prático'? Museologia e Patrimônio, 1(1), 101-105.

Thompson, J. (1974). Library Power: A New Philosophy of Librarianship. London: C. Bingley.

Todd, R. (2003). Adolescents of the Information Age: Patterns of Information Seeking and Use, and Implications for Information Professionals. School Libraries Worldwide, 9(2), 27-46.

Trant, J. (2009). Emerging Convergence? Thoughts on Museums, Archives, Libraries and Professional Training. Museum Management and Curatorship, 24 4), 369-387.

Urquhart, D. (1981). The Principles of Librarianship. Metuchen: Scarecrow.

Usherwood, B.; Wilson, K., Bryson, J. (2005). Relevant Repositories of Public Knowledge? Libraries, Museums and Archives in the "Information Age". Journal of Librarianship and Information Science, 37(2), 89-98.

Vega-Almeida, R. L., Fernández Molina, J. C., Linares, R. (2009). Coordenadas paradigmáticas, históricas y epistemológicas de la ciencia de la información: una sistematización. Information Research, 14(2). 
Ventura, J. (2002). Bibliotecas e esfera pública. Oeiras: Celta.

Vergo, P. (ed.) (1991). The New Museology. London: Reaktion Books.

Vickery, B., Vickery, A. (1987). Information Science in Theory and Practice. London: Bowker-Saur.

Wersig, G. (1993). Information Science: The Study of Postmodern Knowledge Usage. Information

Processing \& Management, 29(2), 229-239.

Wythe, D. (2007). New Technologies and the Convergence of Libraries, Archives, and Museums.

RBM: a Journal of Rare Books, Manuscripts, and Cultural Heritage, 8(1), 51-55.

Yarrow, A., Clubb, B., Draper, J.-L. (2008). Public Libraries, Archives and Museums: Trends in Collaboration and Cooperation. The Hague: International Federation of Library Associations.

Zandonade, T. (2004). Social Epistemology from Jesse Shera to Steve Fuller. Library Trends, 52(4), 810-832.

Zeller, T. (1989). The Historical and Philosophical Foundations of Art Museum Education in America. In: N. Berry \& S. Mayer (eds.). Museum Education: History, Theory and Practice (10-89). Reston: National Art Education Association.

Zorich, D., Waibel, G., Erway, R. (2008). Beyond the Silos of the LAMs: Collaboration Among Libraries, Archives and Museums. Dublin: OCLC Online Computer Library Center.

Zorich, D. (2010). A Survey on Cultural Heritage Initiatives and Their Sustainability Concerns. In: R. Parry (ed.). Museums in a Digital Age (406-416). Oxon: Routledge.

\title{
Dialog nauki o informacji z archiwistyką, bibliotekoznawstwem i muzealnictwem: ostatnie doświadczenie brazylijskie
}

\begin{abstract}
Abstrakt
Cel/Teza: W artykule omówiono teoretyczne podstawy archiwistyki, bibliotekoznawstwa i muzeologii, które dyscypliny te dzielą ze sobą oraz z nauką o informacji.

Koncepcja/Metody badań: Artykuł zawiera systematyczny przegląd kluczowych ustaleń każdej z omawianych dyscyplin, zaczynając od tekstów podstawowych i przechodząc przez różne okresy, obszary geograficzne i tradycje myślowe.

Wyniki i wnioski: Przedstawiony został kontekst historyczny, w którym powstały trzy omawiane dyscypliny, oraz wskazano ich rozwój teoretyczny w XX w., który spowodował odrzucenie wcześniej dominujących paradygmatów. Stwierdzono, że koncepcja informacji, którą badano ostatnio, może sprzyjać postępowi perspektyw teoretycznych w tych trzech obszarach i wskazano na możliwość dialogu epistemologicznego.

Ograniczenia badawcze: Przegląd literatury skupiono na badaniach, które miały największy wpływ na naukę brazylijską. Przegląd taki można rozszerzyć na inne kraje i inne teorie.

Zastosowania praktyczne: Wyniki przedstawionych badań mogą stanowić koncepcyjną podstawę dla uniwersyteckich programów kształcenia z zakresu archiwistyki, bibliotekoznawstwa i muzealnictwa, tak jak ma to już miejsce w Brazylii. Mogą też inspirować do porównań z innymi krajami. Oryginalność/Wartość poznawcza: Niewiele jest opracowań łączących analizę archiwistyki, bibliotekoznawstwa i muzeologią; jeszcze mniej wiąże te dyscypliny z nauką o informacji. Autor wierzy, że rozważenie ram teoretycznych wszystkich tych dyscyplin razem będzie korzystne dla nich wszystkich.
\end{abstract}

\section{Słowa kluczowe}

Archiwistyka. Bibliotekoznawstwo. Informatyka. Muzeologia. 
CARLOS ALBERTO AVILA ARAUUJO is Associate Professor at the School of Information Science at the Federal University of Minas Gerais, Brazil, of which he was director from 2014 to 2017. Doctor in Information Science, with post-doctorate from the University of Porto, Portugal (2010) and the University of Salamanca, Spain (2019). President of the Association for Education and Research in Information Science of Iberoamerica and the Caribbean (Edicic).

Contact to the Author:

casal@eci.ufmg.br

School of Information Science

Federal University of Minas Gerais

Av. Antônio Carlos 6627 - Pampulha

Belo Horizonte, Brazil - 31270901 